\title{
Forensic Fiction and the Normalization of Surveillance
}

\author{
Liv Hausken
}

\begin{abstract}
This essay investigates forensic fiction as a trend in televised crime fiction and argues that this trend or subgenre is particularly interesting if we are to understand how surveillance is portrayed in contemporary society. The essay looks particularly into an extremely popular example of forensic fiction, namely CSI and its two spin-offs CSI: NY and CSI: Miami. Through a discussion of the conceptions of knowledge, crime and power, which seem to come forth in the three CSI series, the present article argues that the particular blend of technological optimism, positivism and moralism that can be witnessed in forensic fiction in general, and in CSI in particular, is important to understanding how popular culture lends a certain normalization of surveillance to everyday life.
\end{abstract}

Keywords: forensic fiction, crime fiction, surveillance, surveillant assemblage, moralism, CSI, popular culture

\section{Introduction}

Our Western world has been characterized as a society of surveillance. After the collapse of the bifurcated world of the Cold War in 1989 and the declaration of a global war on terror in the aftermath of the terrorist attacks of 9/11 2001, the implementation of surveillance techniques has increased tremendously. This has stimulated an academic interest in surveillance studies. In media studies, however, surveillance has not been given much scholarly attention, despite the fact that this field has a special interest in power and democracy as well as in freedom of speech and technologies of information. One may argue that media technologies are similar or parallel to surveillance technologies and that it could be worthwhile to study not just televised broadcasting, but also closedcircuit television as a technology and cultural form (cf. the classic text by Raymond Williams 1974). The fact that monitoring functions are built into media technologies seems to have stimulated some interest among students in so-called "new" and "social" media (see Magnet and Gates 2009). This indicates much more ubiquitous opportunities for surveillance than have previously been possible. It also reflects the importance of a new concept of surveillance. As Kevin D. Haggerty and Richard V. Ericson have argued in their influential article "surveillant assemblage" (2000), “... we are witnessing a convergence of what were once discrete surveillance systems to the point that we can now speak of an emerging 'surveillant assemblage'. This assemblage operates by abstracting human bodies from their territorial settings and separating them into a series 
of discrete flows. These flows are then reassembled into distinct 'data doubles' which can be scrutinized and targeted for intervention" (Haggerty and Ericson, 2000, p.606). In CTRL [SPACE]: Rhetorics of Surveillance from Bentham to Big Brother, editors Levin, Frohne, and Weibel (2002) have collected articles and art works that seem to demonstrate a concept of surveillance on the model of the panopticon, the concept of a design that allows a watchman to observe (-opticon) all (pan-) inmates of an institution without them being able to tell whether or not they are being watched. Some have argued that reality television has turned this constant risk of being observed into a strong desire for self-exposure and that "Big Brother" was "the series that made surveillance acceptable" (John Walsh 2010). ${ }^{1}$ Even if this had been correct, this coupling of Reality TV and surveillance seems to conceal the fact that surveillance today has changed dramatically, that it takes different forms and involves other risks.

In the present essay, I will look into a trend in televised crime fiction that we may call forensic fiction. I will argue that this trend is particularly interesting if we are to understand how surveillance is portrayed today. After a brief outline of the basic features of forensic fiction exemplified by television series from the English-speaking world, I will go more specifically into one of the most popular forensic fiction series today, CSI, to concretize the argument and exemplify my points. ${ }^{2}$

The politics of surveillance are currently being negotiated in a whole range of arenas. One of them is the domain of popular culture (see also Levin 2002, p.581). As underlined by Andrew Martin in his article "Popular Culture and Narratives of Insecurity", what is of interest in the fictions of popular culture is their influence on the ways in which we perceive the world in general and our place within it in particular (Martin 2007 p.107). To understand how popular culture circulates cultural meaning, we should look into what is taken for granted in popular culture and see if this can help us see and conceptualize important issues in a more qualified manner. This is not necessarily an easy task. As Ronald R. Thomas argues in Detective Fiction and the Rise of Forensic Science, "popular cultural forms often become quickly settled in the perceptual frame of their civilization, and therefore appear obvious and or even invisible in retrospect. But in fact, such forms may require more intense critical analysis than do 'higher' art forms, because they have so subtly invaded and ordered massive, unsorted psychic and cultural materials from the historical moments in which they appeared" (1999, p.5). I will argue that popular culture plays an important part in the normalization of surveillance in today's society. This is not to claim a singular influence for popular culture in and on contemporary life, but rather to insist that the presentations of popular culture are crucial elements in the production of knowledge and perception (see also Martin 2007 p.107). This is why we should take fiction and entertainment seriously.

\section{Forensic Fiction}

Crime fiction has always been about social order, the criminal violation of order, and the restoration of order. However, along with the changing perception of social threats, transforming political climates, and evolving definitions of what or whom is to be protected (the common man or a particular economic or cultural arrangement of social groups), heroes and their methods have also changed throughout history. In the 1950s, private detectives protected their innocent clients. In the 1980s, the police were the heroes. 
Today, forensic scientists and lab technicians have ascended to the role of detectives and police. Nowhere is this more remarkably present than on television.

During the 1990s, a growing number of televised detective stories included forensic pathologists and other forensic scientists in their detective teams. Earlier, we had witnessed the coroner Dr R. Quincy (Jack Klugman) investigating suspicious deaths in Quincy M.E. (NBC 1976-1983). However, Quincy and his colleague Sam Fujiyama (Robert Ito) acted as amateur detectives. Based on their inspections of dead bodies, they followed clues and created hypotheses that didn't necessarily match the theories concocted by the police. In 1997, Australia's Nine Network launched Murder Call (1997$2000)^{3}$ following a classic clue-puzzle plot, combining mystery, action and suspense, spiked with humor, romance and a touch of the bizarre. The series centered on homicide detective Tessa Vance (Lucy Bell) and her partner Steve Hayden (Peter Mochrie) as they worked closely with "Tootsie", Dr Imogen "Tootsie" Soames, the pathologist performing the autopsies (played by Glenda Linscott), as well as with a police photographer and the leader of the crime lab.

One year before "Tootsie" entered the scene, BBC One aired Silent Witness (starting in 1996 and still running), which focused on a whole team of forensic pathology experts and their investigations into various crimes. The program originally followed the team of the forensic pathologist Dr Sam Ryan (Amanda Burton). There has been a succession of regular characters, changing almost every season, but two or three forensic pathologists have always been central characters in the show. A new character, Dr Nikki Alexander (Emilia Fox), was introduced to the team in 2004, first as a forensic anthropologist (enlisted by the team to help analyze bones), and then later, she was also accepted as a pathologist. Silent Witness may be considered a prototype of the developing genre we may call forensic fiction. The BBC's Waking the Dead (2000-2011) and Fox's Bones (2005 and still running) are shows in this genre that are also worth mentioning. ${ }^{4}$

In the BBC-produced series Waking the Dead, Detective Superintendent Peter Boyd (Trevor Eve) is the leader of a multi-discipline police team of detectives and scientists, called the Cold Case Squad, which investigates old, unsolved murder cases using new methods and technology that may not have been available during the original investigation. The team includes a psychological profiler and a forensic pathologist.

A multi-discipline team of detectives and scientists can also be seen in the American crime drama television series Bones, which premiered on the Fox Network in 2005. The show is based on forensic anthropology and forensic archaeology, with each episode focusing on an FBI case file concerning the mystery behind human remains brought by FBI Special Agent Seeley Booth (David Boreanaz) to the forensic anthropologist Dr Temperance "Bones" Brennan (Emily Deschanel). The rest of the forensic team includes a forensic artist and specialist in craniofacial reconstruction, an entomologist who is also an expert on spores and minerals, a candidate who, in the course of the show, receives his doctorate in Forensic Anthropology and Mechanical Engineering and becomes a professional forensic anthropologist, as well as the head of the Forensic Division who is also a pathologist, and finally, a psychologist.

Compared to Silent Witness, presenting a team consisting solely of forensic pathologists (underlined by the introduction of Dr Nikki Alexander as a forensic anthropologist who has to prove that she has the necessary qualifications to fill the vacancy for a 
pathologist left by Professor Ryan, although she was initially stated to have a PhD in anthropology and not a medical qualification), Bones represents a rich variety of forensic sciences. In this way, Silent Witness may be closer to a popular conception of forensic science, envisioning dead bodies and autopsies. Not all forensic science is like this, but forensic pathology is (see, e.g., Siegel \& Mirakovits 2010 p.8).

In reality, any science can be a forensic science if it has some application to court or criminal matters (Siegel \& Mirakovits 2010 p.6-7). With such a broad and functionally oriented definition of forensic science, the fictions about forensic science offer very rich and varied material for a genre under development, including both respected fields like math and more dubious sciences like the psychology of body language. Fictional forensic science would then include series like Num3ers (CBS 2005-2010), where mathematics and theoretical physics are applied to solve crimes. From the more dubious part of the spectrum of sciences, the genre would also include a show like Lie to Me (Fox 20092011) where Dr Cal Lightman (Tim Roth) and his colleagues at the Lightman Group accept assignments from third parties (commonly local and federal law enforcement), and assist in investigations, reaching the truth through applied psychology, interpreting micro-expressions through the "Facial Action Coding System" and body language.

Forensic fiction is fictional forensic science. It is not forensic science fiction: The time is not set in the future, but in contemporary life. Technology is not futuristic, but existing or just-to-be-invented. Scientific principles are known. They are not new, nor do they strain known laws of nature (like time travel, wormholes or faster-than-light travel). And perhaps most importantly of all, technology is not considered a problem (and an instrument for disaster in the hands of a mad scientist), but an opportunity for righteous scientists to solve mysteries.

Forensic fiction is a genre that merges the mystery plot with forensic science. Some may consider it a subgenre of the police procedural, as such shows often depict forensics and autopsies along with a number of other police-related topics. Just like the police procedural, forensic fiction is a piece of detective fiction, which attempts to convincingly depict the activities of a professional team of investigators as they inquire into crimes. Unlike the classic detective novels that usually concentrate on a single crime, both forensic fiction and police procedurals frequently depict investigations into several unrelated crimes in a single story. But in forensic fiction, the team consists primarily of forensic scientists, not police detectives (even if police detectives may be among the main characters) and the working place is not (primarily) a police department but a medico-legal lab (like the Jeffersonian Institute in Bones, the Thomas Lyell Centre in Silent Witness, or the Las Vegas Crime Lab in CSI).

Forensic fictions often blur the distinctions between three different functions: forensic science, crime scene investigation, and criminal investigation. Crime scene investigators collect evidence from a crime scene; forensic scientists analyze the evidence in a crime lab, while the police or other official agencies that have the authority to investigate and launch criminal charges usually conduct criminal investigations. In forensic fiction, the same team often performs all of these functions. Based in a crime lab, but with far more extensive competence and power, our heroes in forensic fiction seem to represent everything we need to restore social order. 


\section{CSI as Forensic Fiction}

One of the most popular forensic fiction series on network television is CSI: Crime Scene Investigation (from 2000 onwards). CSI is an Emmy Award-winning CBS television series that chronicles the investigations of a team of Las Vegas forensic scientists as they try to uncover the circumstances behind mysterious deaths. The popularity of this television series has led to two spin-off series - CSI: Miami (since 2002) and CSI: $N Y$ (since 2004). Available for viewing on mobile phones, the series is also the subject of novels, graphic novels, computer games, mobile games, websites, online discussion forums, a large amount of fan-made art, and even an exhibit at the Chicago Museum of Science and Industry, with a supporting website. ${ }^{5}$ The original television series has averaged more than 25 million viewers in the US each week and has been syndicated in more than 70 countries (see Navid 2007, p.33). It has been recognized as the most popular dramatic series internationally by the Festival de Télévision de Monte-Carlo, which has awarded it the "International Television Audience Award (Best Television Drama Series)" three times. CSI's worldwide audience was estimated to be over 73.8 million viewers in 2009. In 2011, CSI appears to be the most-watched series in the world, once again. ${ }^{6}$ Because of its popularity and comprehensive distribution, it may be particularly useful to look into a franchise like CSI. In the following, I will concentrate on the three televised crime fiction shows in general and the original TV series in particular.

The forensic team members on CSI are identified as "Crime Scene Investigators" working for the Las Vegas Police Department. The main characters can be characterized as being a combination of forensic scientist, crime scene investigator, and criminal investigator. Assisting them are a trace technician, the Clark County Coroner, an Assistant Coroner, and the LVPD Captain Jim Brass (Paul Guilfoyle), an ex-New Jersey cop, turned CSI, turned cop again.

The series has been heavily criticized by police officers and district attorneys for portraying an inaccurate image of how the police solve crimes and for its lack of realism in that the show's characters not only investigate crime scenes ("process", as their real-world counterparts do), but also conduct raids, engage in suspect pursuit and arrest, interrogate suspects, and solve cases, all of which fall under the responsibility of uniformed officers and detectives, not CSI personnel. ${ }^{7}$ CSI has also often been criticized for the level and explicitness of graphic violence and sexual content. Along with its spinoffs, this extremely popular television series has allegedly stretched the boundary for what is considered acceptable viewing for prime-time network television. ${ }^{8}$ All this has not gone unnoticed among scholars of media and television. However, ideas of social order, security and crime on CSI and similar programs have been given less attention.

On CSI, the investigators use physical evidence to solve murders. Like all forensic fiction, the techniques of forensic science appear to be the main method with which to restore social order. However, to solve crimes and restore order, admission of evidence requires authentication. In most crime fiction, an object of evidence is authenticated through the interrogation of suspects and through witness statements. In classic crime fiction, authentication of physical evidence appears to be secondary to questions of motive and opportunity. In forensic fiction, physical evidence comes first, and on CSI, questions of motive and opportunity are hardly present at all. Several scholars have remarked how CSI represents a change of focus from motive to technical evidence. "The material context indicts the suspects, not their psychological motivation", as Silke Panse 
puts it (2007 p. 155). According to Deborah Jermyn, "Certainly, one of the distinctive generic shifts the program has brought to TV crime drama is its relative disinterest in the criminal mind and Gil Grissom's recurrent aphorism is that it is a CSI's job to read the evidence, not look for motive" (Jermyn 2007 pp. 80-81). However, the question remains: how is an object of evidence authenticated? On CSI, evidence is authenticated in the networked database.

The networked database is the centerpiece of information on CSI. It is the main source of detailed and reliable information of all kinds, seemingly non-biased, and always easily available by pressing a button once or twice on the computer keyboard. This networked database gives access to the Forensic Medical Journal, the Dental Society Database, the Combined DNA index system (CODIS), a gun ownership database, and every other database one can possibly think of. All this information is not only available, it is also extremely rich, seemingly neutral, always relevant and constantly updated.

Let me take the photographic practices on CSI as an example. The narrative universe of CSI is a universe where nearly every member of the forensic team has a camera and will act as a crime scene photographer whenever they see a physical object that might be turned into technical evidence. The photographs are then loaded into a computer, modified and made comparable to other photographs.

Like most crime series on television, there are two genres of photographs on CSI: portraits and crime scene shots. There are more photographs on CSI than on other crime shows, but a more striking difference between the photographs on CSI compared to other crime shows is the source of the photographic portraits, both of victims and of suspects. In the classic crime series, the detective borrows a portrait of the victim from the victim's relatives. This portrait is normally a few years old, of moderate technical quality, and featured by the situation it was made in, be it a Christian confirmation or a reunion from high school. Portraits of suspects are normally found either by coincidence in someone's home or in the police records, and in both cases, are equally characterized by their situation. But on CSI, the main source of all portraits seems to be the networked database. Like all information from this networked database, the photographic information is completely prepared and conditioned for immediate action.

More or less everyone's photographs is available for the investigators on CSI, ready to be called upon to aid in the identification of suspects. A short sequence from CSI: NY may illustrate this process of identification. This example is taken from the first episode of Season 3 (People With Money). A man has been killed on the Brooklyn Bridge. We know that he was about to propose marriage to a woman that night, because an engagement ring is found in his jacket and he has apparently made some special effort to make the Brooklyn Bridge appear particularly romantic that night, as one can see from the light on the building from the other side, saying: Marry Me. Our friend from the lab takes a photo of that building, zooms in about 100 times (or probably even more), so that one can vaguely see a silhouette through one of the windows, a window that is a bit brighter than the others. It is the office window of the deceased. Someone was there while the crime scene investigators were examining the dead body on the bridge. The computer is then able to measure the proportions of this face, construct a model, turn this model en face and - with the aid of facial recognition software - run it through their all-encompassing identification records, resulting in one clearcut and unambiguous match. ${ }^{9}$ No wonder they don't need witnesses. 
CSI has redefined the notion of witness (see also Navid 2007). In all forensic fiction (and particularly in fictional forensic pathology), the dead body is treated as the first witness (as indicated by the title, Silent Witness, and repeatedly stated by the characters on $C S I$ ). In CSI, however, the role of the living human witness is more or less ruled out and replaced by what we now are able to identify as a broad spectrum of technologies of surveillance: all sorts of personal data collected through social security numbers, travel documents, camera images, fingerprints, retinal scans, application forms - briefly put: the constant computer-based scrutiny of ordinary daily life for citizens and consumers as they participate in contemporary societies. As Haggerty and Ericson have argued, the 'surveillant assemblage' operates today - in real life - "by abstracting human bodies from their territorial settings and separating them into a series of discrete flows. These flows are then reassembled into distinct 'data doubles' that can be scrutinized and targeted for intervention (ibid.). As underlined by Maria Los, also with reference to real life and not to fiction, "[...] products of surveillance technologies are increasingly construed as a new form of truth, more real and authoritative than any subjective sense of reality held by individuals. The data double is more real than the person behind it" (Los 2008 p.86). In the real world, there are some controversies connected to retention of electronic data and to the possibilities of linking different databases and making the information available to the general staff of the police, or to hospitals or other public institutions. ${ }^{10}$ On $C S I$, this is not an issue: The society portrayed on CSI is a fictional world of extensive surveillance. All information from the fictional "surveillant assemblage" is made available to the investigators. All they need is a medico-legal lab and a networked database.

\section{Surveillance in CSI}

How, then, is surveillance presented on CSI? A short answer could be: hardly at all! Compared to the HBO series The Wire (HBO, from 2002) - where we, as the title suggests, witness the detectives constantly wiretapping the suspects, watching them from a distant roof, taking photograph of drug dealers in action - on CSI, the detectives are hardly ever waiting in a car outside someone's house or sitting an a café with cold coffee behind a newspaper spying on someone. They don't talk about wires, they normally don't plant any bugs in people's houses, and they generally don't discuss surveillance techniques. This may explain why so few have discussed the role of surveillance on CSI. In a peculiar way, it seems invisible.

One of the very few studies about surveillance on CSI that I have been able to trace is a Master's thesis by Canadian student Sanam Navid, who has compared CSI to the television series Law \& Order, discussing the concept of the witness in these two programs. ${ }^{11}$ In this Master's thesis, both these television series are interestingly enough called "Narratives of Surveillance". This is due to the fact that these fictional worlds rely heavily on surveillance techniques. "Narratives of Surveillance" is an intriguing label for CSI because this fictional universe provokes the general idea of "Surveillant Narration" in popular culture. "Surveillant Narration" normally refers to stories where people are actively watching or being watched, or where surveillance techniques are thematically or stylistically visible throughout the story or in key sequences. An early example can be found in the legendary sequence in Call Northside 777 (1948), where 
a panopticon's articulation of power can be witnessed. ${ }^{12}$ The term Surveillant Narration also refers to films like Alfred Hitchcock's Rear Window (1954), Michael Powell's Peeping Tom (1960), Francis Ford Coppola's The Conversation (1974), Peter Weir's The Truman Show (1998), ${ }^{13}$ and Steven Spielberg's Minority Report (2002), to mention some of the most well- known. ${ }^{14}$ These are all films in which surveillance camera or monitors can be seen, and where the power of surveillance is demonstrated. "Narratives of Surveillance" seem to be less prevalent in televised fiction. I have mentioned The Wire. Another great example is 24 (Fox), as well as, to a certain extent, The Sopranos (HBO 1999-2007). These can figure as examples from television in which surveillance techniques are visibly present and where the awareness of being watched is extensive.

On CSI, on the other hand, surveillance is not in focus. In the midst of everyone's attention, we find the lab technicians collecting data from the crime scene, photographing and measuring items, and bringing physical evidence back to the lab. They look at this material through optical instruments; they visualize non-visual material, and they use the technologies of visualization as instruments to identify the criminal. The efficiency of this forensic machinery of identification is presented as the core of the show. The "surveillant assemblage" made available by the networked database seems to be taken for granted. As Lorraine Daston and Ferando Vidal state (in The Moral Authority of Nature, 2004), "The best kind of authority works invisibly. If it must brandish weapons and admonish its subjects, it only advertises its weakness; the stablest order is unfelt and unquestioned" (Daston and Vidal 2004 p.21). This is how surveillance is presented on CSI: like a second nature, unfelt and unquestioned.

One may argue that the faith shown in the omnipotence and omnipresence of satellites and fiber optics on display in the series 24 is also an example of importance for a debate about the normalization of surveillance in today's society. The positive presentation of surveillance in this series could be critically discussed in contrast to the doubt in phone taps and recording devices in The Wire, in relation to how these popular and highly awarded series negotiate the politics of surveillance. ${ }^{15}$ Nevertheless, I will argue that the invisibility of ubiquitous surveillance in the extraordinary widespread fictional universe of CSI makes this particular fiction an important case in discussions of the normalization of surveillance in contemporary societies.

The unfelt and unquestioned practices of surveillance on CSI are the first of several elements of importance in understanding how the program lends a certain sense of normalization to surveillance in contemporary societies. However, other factors also play major roles. One of the most eye-catching is the way the program celebrates the efficiency of technology. ${ }^{16}$ It may be worth noting that a large part of the "Surveillant Narration" films mentioned above belong to the genre of science fiction. When it comes to technology, CSI is just as amazingly impressive as any science fiction work. As the Australian pathologist Shelley Robinson once remarked, rather briefly and to the point, in her commentary on CSI's technical equipment, "My department doesn't have that particular laboratory instrument" (Vinall \& Robinson 2007, p. 205). But in contrast to the genre conventions of science fiction, there are no dystopian dimensions associated with the advanced technology on CSI. The technological apparatus of CSI does not present any future dystopia, but rather a contemporary utopia, a fiction with technologies already in use or just-to-be-invented, technologies that can help us solve society's problems, here and now. 
The absence of any critical distance to technology on CSI involves a lack of reflection on the security of information (that is, the constant risk of losing sensitive data) and the potential use and misuse of information. This can be contrasted with a whole range of crime series that may rely heavily on surveillance technologies but nevertheless allow critical reflection as part of the plot as such (showing misinterpretation of data or misuse of surveillance techniques) or as part of the milieu described, for instance the critical eye of a character like John Munch (Richard Belzer), who has a long career as a conspiracy theorist from the Baltimore Police Department (Homicide: Life on the Street), via the X-Files and The Wire to Law \& Order: Special Victims Unit. On CSI there are no characters even remotely similar to the skeptical and mistrustful John Munch.

This trust in technologies on CSI is important for understanding the status of surveillance in this fictional universe. It is also an indicator of the show's presentation of power, a third component for consideration in this discussion about how CSI lends a certain normalization of surveillance to everyday life. Because, yet again, and just like the surveillance apparatus, it appears to be nearly invisible.

In classic detective fiction, there is often a fundamental narrative conflict between the genius detective and his boss, be it the head of department, the mayor, or the city administration in general. The ongoing conflict between the grumpy, British detective Jack Frost (David Jason) and the bureaucratically minded Superintendent Norman Mullett (Bruce Alexander) on the ITV series A Touch of Frost may serve as an example (Yorkshire Television, UK). A less clear-cut instance of bureaucratic power, but nevertheless a classic conflict between the genius detective and his boss, can be found on the television series House MD (Fox), a rather classic detective series disguised as a hospital drama, with a narrative drive very much fueled by the relation between the genius detective in diagnostics Dr Gregory House (Hugh Laurie) and the administrative leader Dr Lisa Cuddy (Lisa Edelstein). This conflict does not appear on CSI. There are no detectives on CSI struggling against the administrative reason of the police, the mayor or some other administrator in charge.

I will argue that the lack of conflict between the detective's way of thinking and the bureaucratic mind of his boss does not only have to do with a seeming agreement between the two. This lack of conflict can also be seen as a sign of there not being any genius detective/scientist on CSI. Admittedly, Gil Grissom (who was head of the department for no fewer than nine years) may have had some tendencies in that direction, but even Grissom - with his specialty in bugs - was a man with knowledge, but not a detective with intuition, hunches, gut feelings, or the other typical qualities of a Sherlock Holmes, a Miss Marple, or a Dr House, for that matter - the ability to perform the logic that Charles Sander Peirce called abduction (in contrast to both induction and deduction), the logic of the qualified guess. The investigators on CSI do not follow their intuition. They "follow the evidence", as they constantly advise each other to do. There is no socially troubled, arrogant character with uncompromising trust in his gut feelings. There is no detective genius. CSI seems to demonstrate that science can be performed by technicians! With a little training, anyone could have done this. In the end, they would all come to the same conclusion: They trust their own eyes because their eyes are just as good as anybody else's. They are the same: Culture, society, gender, class, political opinion, and conflicting perspectives do not make any difference. 
The series ignores the fact that everyone is a cultural being, that each person sees something as something, that they understand things from particular perspectives in everyday life as well as in science. As Karen Lury has pointed out:

The science practiced in the programme is $[\ldots]$, post-Enlightenment but premodern, in that it is a supremely rational discourse, that is presented without the doubts and confusions opened up by twentieth-century scientific discoveries such as the theories of relativity and chaos. These are theories which insist that the process of interpretation and the position of the scientific observer must and do have an impact on their findings. This is in contrast to CSI where the investigators' role as scientists, and the way in which they interpret or process their evidence, is rarely questioned [...] (Lury 2007 p. 107-108).

Briefly put, CSI seems to legitimize a highly problematic presentation of science, which I will characterize as a revitalization of positivism (see also Lury 2007, and Navid 2007). The prevalence of this neo-positivism can be seen in all the considerations above: in the complete confidence in the neutrality of technology, information and knowledge, and in the lack of power conflicts. This revitalization of positivism is of major importance to understanding the normalization of surveillance discussed here.

Finally, on CSI, crime appears to be a moral question. The crimes and the people committing them disgust the detectives. The show's morality is most clearly expressed in the coda. In the Las Vegas series, this role is most often assigned to the forensic scientist Catherine Willows (Marg Helgenberger). Let me give an example from the coda of an episode called Bite Me (Season 6, Episode 3). The team has just realized that a teenage girl committed the crime: she has killed her stepmother to protect her father. In the very last sequence of this episode, we see Catherine Willows pass the guilty girl in slow motion. Willows has just given a little moral speech to the girl's father, assuming that he knew about and could have prevented the crime, before her morally disapproving gaze moves toward the girl, and the technical slowing of the film seems to write large the perspectives on crime relevant here: There is no doubt they have got the right guy, or in this case the girl, but it is nevertheless striking how there are no valid explanations for the crime - it is simply a case of bad morals.

Sociology doesn't count. Psychology is barely relevant. The contrast to the socially critical traditions of detective fiction is quite apparent. On CSI, there is not only a moral divide between good guys and bad guys, as we also know from classic Hollywood film. CSI presents a moral gap between the detectives representing the moral majority (including us, the audience) and the bad guys, the immoral minority, committing the crimes just because they are bad people.

Why this moralistic attitude toward crime? It seems that the condescending moral judgment that is so explicitly present, particularly in the coda of the series from Las Vegas and Miami, may correspond to the often quite bizarre and sometimes even macabre crimes committed. (Note that both Las Vegas - nicknamed Sin City - and Miami are associated with human avarice and vice, commerce and corruption.) The detectives are disgusted by the crimes, and quite often, the spectacular and devious character of the crimes committed also seems to correspond to their disgust. In Sin City, the bizarre crime seems to legitimize the moralism of the detectives. Together with the idea of technological neutrality and a rather uncritical view of power and knowledge, I will argue 
that a moral explanation of crime and a moral divide between "us" and "them", the moral majority and the evil minority, is one of the most important conditions for an uncritical acceptance of a general surveillance of citizens. If we then add the show's presentation of a society with a ubiquitous surveillance technology without the uncomfortable awareness of being watched by authorities, this moralistic conception of crime seems to legitimize rather comprehensive surveillance. With a technology that can efficiently solve crimes with the assistance of lab technicians and without any moral ambiguities, CSI presents a society in which the bad guys will get caught every single time with the help of an infallible technology of surveillance, detection and identification that we don't have to fear as long as we behave nicely. Why shouldn't we accept a society of total surveillance?

\section{Conclusion}

CSI is not just a show: it is an extraordinary widespread fictional universe spread out in three television series on stationary and mobile platforms, novels, graphic novels, games on several platforms, websites, and a large amount of material in magazines both online and offline. It seems to demonstrate a tendency in crime fiction today: CSI is a whodunit, but there are no persons of interest in the show, not even "the who", the criminal. The plot is not so much driven by the question of who did it, but rather of a methodological spectacle: It is as if these series proclaim again and again: watch us get the bad guys! No one has any questions about the methods. Our heroes are technicians studying physical evidence and solving crimes with the help of technical devices. Science is presented as flashy and cool, making the fictional universe entertaining without genius detectives, conflicts of interpretation, or troubles overcoming the bureaucratic mindset of authorities. It may appear to be an extreme example of forensic fiction on television today. I will nevertheless argue that we find many of the same characteristics in several of the examples of forensic fiction mentioned in this article, as well as in similar shows like NCIS: Naval Criminal Investigative Service (CBS, 2003 and still running) and other crime shows involving law enforcement and counter-intelligence, not to mention in tabloid newspapers and popular magazines.

By examining CSI as a rather extreme but also exceptionally widespread example of contemporary forensic fiction, I have tried to pinpoint some important elements from televised fiction today that should be taken into account in a critical debate about general surveillance in our society: First, the invisibility of ubiquitous surveillance; second, neo-positivism (the idea of the neutrality of technology and knowledge, an uncritical view of power, a general acceptance of a bureaucratic mindset); and third, a moral conception of crime and, more generally, of people's actions and motives.

In short, I am arguing that if we look into the cultural premises of contemporary fictional worlds of popular culture - the things taken for granted - we find an important source of the sense of the given in our own society. More specifically, I will conclude this discussion of how popular culture seems to normalize or to reflect a normalized view of surveillance in today's society by mentioning the three factors we should be more aware of in debates about surveillance, namely the networked information from invisible surveillance, and the tendencies toward positivism and those toward moralism in society today. 


\section{Notes}

1. John Walsh (Wednesday 18 August 2010), Big Brother, http://www.independent.co.uk/voices/commentators/big-brother-the-series-that-made-surveillance-acceptable-2055154.html. These ideas have been challenged by, among others, James Wong (2001).

2. I used the term 'forensic fiction' in an international setting first in 2009, presenting the paper "The visualization of detection in forensic fiction", at Pluralizing Visual Culture: The First Nomadikon Meeting, Bergen, February 20-21 (2009). I have later contributed to development of the notion on several occasions, among them in the paper "The matrix of Surveillance in Forensic Fiction" at a panel with Anne Jerslev, Sofia Bull and Jason Jacobs, at the SCMS conference in Los Angeles, 2010, at the conference Emotions, Media and Crime, Aarhus University, later that year, where I discussed the notion with Elke Weissmann and others, and finally at The Mediation of Security conference, at De Montfort University, Leicester in 2011.

3. Southern Star Entertainment Pty. Ltd., Australia.

4. D.L. Palatinus and Sara Bull use the terms "Forensic Crime Fiction" (Palatinus 2009) and "Forensic Crime Drama" (Bull 2012), respectively, underlining forensic fiction as a part of crime fiction. Because forensic science - often shortened to forensics - investigates facts of interest in relation to criminal or civil law, the notion 'forensic fiction' already signals the connection to crime fiction without limiting the notion to this genre, making it easier to see the connections to other genres, like the thriller and the legal drama.

5. An exhibit at the Chicago Museum of Science and Industry (opened on May 25, 2007) called CSI: The Experience, with a supporting website designed for the benefit of people who cannot visit the exhibit, at CSI: The Experience Web Adventure.

6 According to http://en.wikipedia.org/wiki/CSI:_Crime_Scene_Investigation\#cite_note-2, accessed August 4, 2011. The extreme popularity of this TV series has been credited for a large surge of applications to courses in forensic science (see, e.g., Siegel and Mirakovits 2010, pp. 5-6). Although many police officers and district attorneys have criticized the show (as I will come back to below), some law enforcement agencies have responded positively to the show's influence and are enjoying their new reputation. In the UK, Scene of Crime Officers (SOCO) who gather forensic evidence for the British police, now commonly refer to themselves as Crime Scene Investigators (CSIs) even if they do not analyze evidence or investigate crimes themselves. See for instance the website for Leicestershire Police, http://www. leics.police.uk/join-us/police-staff/scenes-crime-officer.

7. According to the critics, victims and their families are coming to expect instant answers from showcased techniques such as DNA analysis and fingerprinting, when in actual forensic processing, these procedures often take days or weeks, with no guarantee of revealing a "smoking gun" for the prosecution's case. District attorneys state that the conviction rate in cases with little physical evidence has decreased, largely due to the influence of CSI on jury members. I will not go further into these public debates here. See, e.g., Lawson 2009; Toobin 2007; Schweitzer and Saks 2007; Kruse 2010; Cole and Dioso-Villa 2009, and Lovgren 2004.

8. This extremely popular television series has been ranked as among the worst prime-time shows for family viewing by the Parents Television Council in the US nearly every season since its debut. See w2.parentstv.org

9. As the example demonstrates, the biometric system here performs a one-to-many comparison against a biometric database in an attempt to establish the identity of an unknown individual. In biometrics, this is referred to as the identification mode of the system, the most common mode on CSI. Like most forensic fiction, the biometric characteristics on CSI are mainly physiological. On some shows, however, they are also behavioral. An extreme example of the latter can be found in the series Lie to Me (Fox).

10. The controversial Data Retention Directive issued by the European Union (Directive 2006/24/EC) may exemplify the complexity of some of these debates. On April the 8th 2014, the Court of Justice of the

\section{Acknowledgements}

I had the great pleasure of presenting this argument at the international conference The Mediation of Security, 18 May 2011, De Montfort University, Leicester. Early versions of this argument have been presented at the SCMS conference in Los Angeles, March 18, 2010 and the Emotions, Media and Crime conference at Aarhus University, Denmark, September 29 - October 1, 2010. I wish to thank participants for their comments and suggestions. Further, I am grateful for Karen Lury's useful comments on the first draft of the article. I also wish to express my warm thanks to the participants at the Media Aesthetics Workshop, September 3, 2010, at the Department of Media and Communication, University of Oslo. 
European Union declared the Directive invalid in response to a case brought by Digital Rights Ireland against the Irish authorities and others.

11. In the MA thesis, Redefining the Witness. CSI and Law \& Order as Narratives of Surveillance (2007) Sanam Navid argues that while Law \& Order presents a prosthetic witness, CSI displays a post-human conception of witnessing.

12 I am thinking of the sequence in Call Northside 777 (USA, Henry Hathaway 1948) where P.J. O'Neal (James Stewart) walks along the ramparts of the Illinois State Penitentiary in Statesville (see also Levin 2002 p.581).

13. See Levin 2002 and Dietmar Kammerer 2004 p.468.

14. We can also think of films like Fritz Lang's Dr Mabuse, Allen and Albert Hughes' Menace II Society (1993), Phillip Noyce's Sliver (1993), Brian de Palma's Snake Eyes (1998), Barry Levisnon's Wag the Dog (1997), and Mike Figgis’ Time Code (2000).

15. Thanks to Mark Neocleous for encouraging me to clarify this argument.

16. Even if the efficiency of surveillance technology is taken for granted in this show, all other kinds of technologies are on display in the processes of visualization, detection and identification.

\section{References}

Bull, S. (2012) A Post-genomic Forensic Crime Drama CSI: Crime Scene Investigation as Cultural Forum on Science, $\mathrm{PhD}$ thesis, Stockholm University 2012.

Cole, S.A \& Dioso-Villa, R. (2009) “Investigating the 'CSI Effect' Effect: Media and Litigation Crisis in Criminal Law”. Stanford Law Review 61 (6): 1339, 1358. http://papers.ssrn.com/sol3/papers.cfm?abstract_ $\mathrm{id}=1401417$. Retrieved 1 January 2011.

Daston, L. \& Ferando V. (2004, eds.) The Moral Authority of Nature, Chicago and London: The University of Chicago Press

Haggerty, K.D. \& Richard V.E. (2000) "Surveillant Assemblage" in British Journal of Sociology, Vol. 51, No. 4 (December 2000), pp. 605-622.

Jermyn, D. (2007) "Body Matters: Realism, Spectacle and the Corpse in CSI" in Allen, M. (ed.) Reading CSI: Crime TV Under the Microscope, London/NY: I.B. Tauris, pp. 79-89.

Kammerer, D. (2004) "Video Surveillance in Hollywood movies", Surveillance and Society 2(2/3): 464-473.

Kruse, C. (March 2010) "Producing Absolute Truth: CSI Science as Wishful Thinking". American Anthropologist 112 (1): 79-91. doi:10.1111/j.1548-1433.2009.01198.x. http://onlinelibrary.wiley.com/ doi/10.1111/j.1548-1433.2009.01198.x/full\#ss4. Retrieved 1 January 2011.

Lawson, T.F (3 November 2009). "Before the Verdict and Beyond the Verdict: The CSI Infection Within Modern Criminal Jury Trials" (PDF). Loyola University Chicago Law Journal 41: 132, 142. See http:// www.luc.edu/law/activities/publications/1ljdocs/vol41_no1/pdfs/lawson_verdict.pdf, last accessed 1 January 2011.

Levin, T.Y. (2002) "Rhetoric of the Temporal Index: Surveillant Narration and the Cinema of "Real Time"”, in Levin, T.Y.; Frohne, U. \& Weibel, P. (eds.) CTRL [SPACE]: Rhetorics of Surveillance from Bentham to Big Brother, pp. 578-593, MIT Press.

Levin, T.Y., Frohne U. \& Weibel, P. (eds.) (2002) CTRL [SPACE]: Rhetorics of Surveillance from Bentham to Big Brother, pp. 578-593, MIT Press.

Los, M. (2008) "Looking into the Future: Surveillance, Globalization and the Totalitarian Potential" in Lyon, D. (ed) Theorizing Surveillance. The Panopticon and Beyond, Willan Publishing.

Lovgren, S. (23 September 2004). "'CSI Effect' is Mixed Blessing for Real Crime Labs". National Geographic News. http://news.nationalgeographic.com/news/2004/09/0923_040923_csi.html. Retrieved 12 December 2010.

Lury, K. (2007) "CSI and Sound” in Allen, M. (ed.) Reading CSI: Crime TV Under the Microscope, London/ NY: I.B. Tauris, p. 107-121.

Magnet, S. \& Gates, K. (2009) The New Media of Surveillance, Routledge.

Martin, A. (2007) "Popular Culture and Narratives of Insecurity" in Martin, A. \& Petro, P. (eds.) ReThinking Global Security. Media, Popular Culture, and the "War on Terror", pp. 104-116. Rutgers University Press.

Navid, S. (2007) Redefining the Witness. CSI and Law \& Order as Narratives of Surveillance, MA thesis, Carleton University, Canada.

Palatinus, D. Levente (2009) Framing the Body, Staging the Gaze: Representations of the Body in Forensic Crime Fiction and Film. PhD thesis, Peter Pazmany Catholic University.

Panse, S. (2007) "'The Bullets Confirm the Story Told by the Potato': Materials without Motives in CSI: Crime Scene Investigation" in Allen, M. (ed.) Reading CSI: Crime TV under the Microscope, London/ NY: I.B. Tauris, pp. 153-166. 
Schweitzer, NJ; Saks, MJ (12 March 2007). "The CSI Effect: Popular Fiction About Forensic Science Affects Public Expectations About Real Forensic Science" (PDF). Jurimetrics 47: 357-364. Available at http:// www.public.asu.edu/ nschwei/archive/csieffect.pdf. Retrieved 21 December 2010.

Siegel, J.A. \& Mirakovits, K. (2010) FORENSIC SCIENCE - the basics, CRC Press.

Thomas, R.R. (1999) Detective Fiction and the Rise of Forensic Science, Paperback edition 2003, Cambridge University Press.

Toobin, J. (7 May 2007). "The CSI Effect: The Truth about Forensic Science.”. The New Yorker, See http:// www.newyorker.com/reporting/2007/05/07/070507fa_fact_toobin?currentPage=1. Retrieved 28 December 2010.

Vinall, D. \& Robinson, S. (2007) "Dissecting CSI: The View from the Trainee and the Professional" in Allen, M. (ed.) Reading CSI: Crime TV under the Microscope, London/NY: I.B. Tauris, pp. 201-207.

Wong, J. (2001) "Here's Looking at You: Reality TV, Big Brother, and Foucault", in Canadian Journal of Communication, Vol. 26 (2001) 33-45.

LIV HAUSKEN, Dr.art., Professor, Department of Media and Communication, University of Oslo, liv.hausken@media.uio.no 